\title{
Bâvendîlerin Selçuklularla Münasebetleri (433/1042-551/1156)
}

\author{
Akif Rençber*
}

\section{Öz}

Bâvendîler, İran'da Hazar Denizi'nin güneyinde yer alan Taberistan bölgesinin yerel hanedanlarındandır. Bu hanedan, egemenlik sahasını İran coğrafyasına hükmeden yüksek otoriteye bağlı bir şekilde korumayı başarmıştır. Bu çalışmada Selçukluların Taberistan'a hâkim olmasına engel olan coğrafi şartların zorluğu ve Bâvendîlerin Taberistan'ı savunurken kullandıkları stratejinin temel öğeleri olay anlatısı içinde irdelenecektir. Büyük Selçuklu Devleti'nin kuruluşundan yıkılışına geçen süreçte Bâvendîler ile münasebetler, Selçukluların güçlü veya zayıf olması nispetinde değişkenlik göstermiştir. Ayrıca Selçukluların önceliklerine göre ikili münasebetlerde ana unsur değişmiştir. Muhammed Tapar (11051118) döneminde münasebetlerde ana unsur İsmailîler iken Sencer (1118-1157) döneminde Bâvendî hükümdarlarını kesin bir şekilde tabiiyete almak şeklinde olmuştur. Ancak hiçbir zaman Selçuklular, Bâvendî topraklarını ilhak etme gayesi gütmemiş̧ir. Ülkemizde yerel tarih bağlamında İranî unsurların Türk devletleriyle münasebetleri yeterince ortaya konulamadığı için bu çalışma mezkûr hususa dikkat çekmeyi amaçlamaktadır. Ayrıca bu çalışmada Bâvendîler ön plana çıkartılarak ikili münasebetler irdelenmiştir.

Anahtar Kelimeler: Bâvendîler, Selçuklular, Taberistan, Muhammed Tapar, Sencer

Dr. Serbest Araştırmac1, akifrencber@hotmail.com, ORCID: / 0000-0002-1758-6250 


\title{
Relations between Bavandid and Seljuks (433/1042-551/1156)
}

\author{
Akif Rençber*
}

\begin{abstract}
Bavandid are one of the local dynasties of Tabarestan region in south of Caspian Sea in Iran. This dynasty has achieved to preserve its territory of the sovereignty in a way that has been dependent on the high authority that has dominated the geography of Iran. In this study, the difficulty of the geographical conditions that prevent the Saljuks from dominating Tabarestan and the basic elements of the strategy used by the Bavandid in defending Tabarestan will be examined in the event narrative. During the process from the establishment to the collapse of the Great Saljuk State, the relations with the Bavandid have varied in proportion to whether the Saljuks have been strong or weak In addition, the main factor in bilateral relations has changed according to the priorities of the Saljuks. While in the period of Muhammed Tapar (1105-1118) the main factor in the relations has been Ismailîs, during the Sencer period (1118-1157), that has been to take the rulers of Bavandid under the domination. However, the Saljuks have never intended to annex the Bavandid lands. This study aims to take attention to the aforementioned issue, since the relations between Iranian elements and Turkish states cannot be put forth sufficiently in the context of local history in our country. Moreover in this study, bilateral relations have been examined by bringing to the forefront Bavandid.
\end{abstract}

Keywords: Bavandid, Saljuks, Tabarestan, Muhammed Tapar, Sencer

PhD, Independent Researcher, akifrencber@hotmail.com, ORCID: / 0000-0002-17586250 


\section{Giriş}

Bu çalışma; 433/1042 yılında Selçukluların bölgeye gelişi ve idareyi ele alışlarından 551/1156 yılında Büyük Selçuklu Devleti’nin yıkılışına kadar geçen süreçte Bâvendîlerin İspehbediyye kolunun Selçuklular ile nasıl bir ilişki içinde olduğunu analiz etme amaçlamaktadır. Bu bağlamda yerel güç olmaktan öteye geçmeyen Bâvendîlerin, hâkim otoriteyle münasebetlerinin yanı sıra kendi iç dinamiklerinin anlatısı da ele alınacaktır. Ayrıca bu çalışmada neden-nasılcı tarih metodunun da doneleri dolaylı yoldan kullanılmıştır. Ülkemizde İranî unsurların Türk devletleriyle münasebetleri yeterince incelenmediği için bu çalışma, mezkûr hususa dikkat çekmeyi amaçlamaktadır.

Çalışma mikro tarihçilik bağlamında yerel bir hanedanı konu aldığı için yegâne kaynaklarımız yerel tarihlerdir. Bu bağlamda İbn-i İsfendiyar'ın Tarihi-i Taberistan adlı eseri, bu eserden oldukça fazla istifade eden ve geçen yüzyılın İran yerel tarihçiliğinde önemli bir noktada yer alan Erdeşîr Borzger'in Tarih-i Taberistan adlı eseri temel dayanağımız olmuştur. Bunlardan başka Muhammed Hasan Han İtimadü's-Saltana'nın et-Tedvîn fî Ahval-i Cibal-i Şervîn ve Seyyid Zahirüddin b. Seyyid Nasirüddin Maraşî’nin, Tarih-i Taberistan Rûyan ve Mâzenderân, adlı eserlerinden istifade edilmiştir. Yerel tarih anlatılarında kaynaklar kısıtlı olduğu için bu bağlamda bir çeşitlendirmeden bahsedilemez. Dolayısıyla bu çalışmayı yaparken karşımıza çıkan temel sorunlardan biri kaynak yetersizliğiydi. "Bâvendîlerin Selçuklularla Münasebetleri” başlı̆̆ çerçevesinde çalışmada Bâvendîler temel alınacak ve anlatı Bâvendîler üzerinden şekillenecektir.

Bâvendîlerin Selçuklular ile münasebetlerini anlatmadan önce hem adı geçen yerel hanedanın hâkimiyet sahası olan Taberistan hakkında kısaca coğrafî bilgi vermek hem de kadimden zikrettiğimiz döneme kadar bölgenin siyasî sergüzeştini ifade etmek yerinde olacaktır. Aynı zamanda Bâvendîlerin menşeine değinmek icap eder. 46456 km'lik alanıyla Hazar denizi kıyısında yer alan Taberistan (Mâzenderân), günümüzde Bihşehr, Sârî, Kaimşehr, Babil, Âmul, Nûr, Nûşehr ve Tenkabin şehristanlarından müteşekkildir. ${ }^{1}$ Yoğun ormanlık alanlara ve nemli havaya sahip bir böl-

Mustafa Rüstemi, Hüner-i Tabarestan, (Babilsor: İntişarat-i Müessese-i Amuzeş Alî-yi Marlik, 1392), 15. 
ge olduğundan coğrafî konum itibariyle İran'ın diğer bölgelerine nazaran tamamen farklı bir yapıya sahiptir. Bu bölgenin yüksek dağlarla çevrili olması oldukça fazla yağış almasına neden olmaktadır. ${ }^{2}$ Bu özelliklerinden dolayı kışın ideal bir sıcaklığa sahip olan Taberistan, egemen güçlerin kışlak olarak kullandığı bir yerleşim yeri vasfi taşımaktadır. ${ }^{3}$

Bilinen en eski tarihi kayıtları Ahamenişler dönemine kadar uzanan Taberistan bölgesinde 4 toprakların bir kısmı İslam öncesi dönemde ikta suretiyle kabile reisleri veya mahalli liderlere veriliyordu. Bunun karşılığında bu kabile reislerinin bazıları, Sâsânîlere asker temininde bulunup ordu masraflarını karşılıyordu. Sâsânîlerin zayıf düştükleri dönemlerde Taberistan'da bulunan ikta sahipleri boyunduruk altından kurtulmak için isyan ediyorlardı. Bu sebeple Sâsânîler, Taberistan'a tam anlamıyla hâkim olamıyordu. Bu durum özellikle bölgenin batı kısımlarında daha fazla hissediliyordu. ${ }^{5}$

Müslüman Arapların Taberistan'1 fetihlerinden önce bölge de Bâvendîlerin Keyusiyye kolu, Kârîniler, Camasb hanedanı ve Gilanşahlılar bulunmaktaydı. Bölgenin doğusundan batısına bu hanedanlar hüküm sürmekteydi. Bu bağlamda İslam öncesi dönemde Taberistan'da tamamen yerel hanedanların etkinliği söz konusuydu. ${ }^{6}$

Taberistan, Selçukluların idaresine girene dek öncelikle H.3/M.9.H.4/M.10. asırlar arasında Zeydîler adı verilen devletin hâkimiyeti altına girdi. ${ }^{7}$ Daha sonra Büveyhîler, Samanîler ve Ziyarîler arasındaki savaş-

Salih Purgari, "Nigahi be Coğrafya-yi Tarih-i Taberistan der Kurun-u Evvel-i Hicri," ez-Zehra Üniversitesi İnsani İlmler Araştırma ve İlim Dergisi, no. 17-18 (1380): 35.

3 İbn İsfendiyar, Taberistan şehirlerini ikiye ayırarak ormanlık ve ovalık alan şehirleri tasnifi yapar. Ormanlık kesimde yer alan şehirler Âmul, Sârî, Mamtir (مامطير), Rudbest

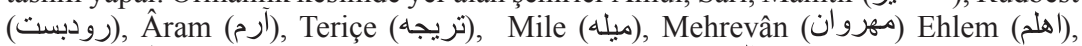

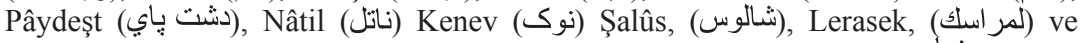
Temişe şehirleridir. Dağlık kesimde yer alan şehirler ise Kelar, Rûyan, Nemar (نمال) (نمار) Kecuye

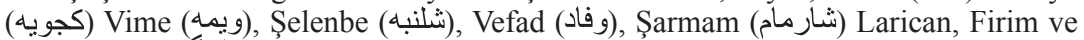
Hezargeri (هز أركري) şehirleridir. (Bahaüddin Muhammed b. Hasan İbn İsfendiyar, Tarih-i Taberistan, tsh. Abbas İkbal (Tahran 1386), 1:94-95.

4 Hüseyin Samedî, Ketabnâme-i Mâzenderân, Sazman-ı Bername-i Ostan-ı Mâzenderân, (Sârî 1372), 1:7.

$5 \quad$ Salih Purgari, "Nigahi be Coğrafya-yi Tarih-i Taberistan," 42.

6 Parvaneh Pourshariati, Decline and Fall of The Sâsânîan Empire, (New York: Tauris, 2008), 287-303.

7 Abdurrafi Hakikat, Tarih-i Conbiş-i Serbedaran ve Diger Conbişha-yi İraniyan der Kurun-u Heştom Hicri, (Tahran: İntişarat-1 İlmi, 1363), 98-99. 
larda sürekli el değiştirdi. Taberistan, 360/971'de Ziyarîlerin idaresine girdikten sonra 370/981'de Büveyhî lideri Adudüddevle tarafindan ele geçirildi. ${ }^{8}$ Selçuklu Devleti kurulduktan sonra yaşanan hızlı fetih hareketleriyle Taberistan'a kadar ulaşılmış, bu bağlamda Tuğrul Bey, Kutalmış'a Taberistan'ın fetih icazetini ve bölgenin idaresini tevdi etmiştir.'

426/1035'de Gazneli Mesud, Âmul'e kadar gelerek Ziyarîlerin tasarrufunda olan Gürgan ve Taberistan'ı hâkimiyeti altına aldı. ${ }^{10}$ Ancak bir müddet sonra Selçuklular, Gaznelileri mağlup ederek topraklarını ilhak etmek amacıyla harekete geçtiler. 433/1042 yılından yerel hâkim Enuşirvan'ın itaatini arz etmesi ve yüz bin dinar vergi vermesi şartıyla barış yapıldı. Böylece bölgenin bir kısmı Selçuklu idaresi altına girdi. Bununla beraber Pâdüspânîler ve bazı yerel hanedanların bağımsızlıkları devam ediyordu. ${ }^{11}$ Bu olay, Bâvendîlerin Keyusiyye kolunun son temsilcisi II. Kârin (419/1028-466/1073) döneminde gerçekleşti. ${ }^{12}$

Öte yandan Bâvendîlerin menşeine değinecek olursak: Bâvendîler, Sâsânî hükümdarı Kubad'ın torunu Bâv'a dayanmaktadır. İlk olarak merkezleri dağlık bölgede yer alan Firim şehriydi. Ancak zaman içinde güçlenmelerine paralel olarak başta Taberistan olmak üzere bölge dışında da hâkimiyet sahalarını genişletme çabası içinde oldular. Hanedan, "İspehbud" veya "Melikü'l-Cibal" adlarıyla da bilinmektedir. 45/665-750/1349 yılları arasinda varlık gösteren bu hanedan, sirasıyla Keyusiyye, İspehbediyye ve Kinhariyye olmak üzere üç kola ayrılmaktadır. ${ }^{13}$ Çalışmamızın zaman ara-

Osman Gazi Özgüdenli, “Taberistan”, (İstanbul: TDVİA 2010), 39: 322.

9 Reşidüddin Fazlullah, Camiü t-Tevarih Selçuklu Devleti, çev. Erkan Göksü-Hüseyin Güneş, (İstanbul: Selenge Yayınları, 2010), 105.

10 İbnü'l-Esir. el-Kamil fi't-Tarih Tercümesi. çev. Ahmet Ağırakça vd., (İstanbul: Hikmet Neşriyat, 2008), 8: 53-54; Reşidüddin Fazlallah, Cami Al-Tavarih Selçuklular Tarihi, (Yay. Ahmed Ateş ), TTK Yayınları, Ankara 1999, s. 13; Azizullah Beyât, Tarih-i Tatbiki-yi İran Ba Keşverha-yi Cihan, (Tahran: Müesssese-i İntişarat-1 Emir Kebir, 1384), 247.

11 İbnü'l-Esir, el-Kamil fi't-Tarih, 8: 94; Azizullah Beyât, Tarih-i Tatbiki-yi Iran Ba Keşverha-yi Cihan, 260; Özgüdenli, "Taberistan,” 322.

12 Erdeşir Borzger, Tarihi-i Taberistan, tsh. Muhammed Şükrî Fûmeşî, (Tahran: Neşr-i Resâneş, 1388), 2: 465.

13 Muhammed Hasan Han İtimadü's-Saltana, et-Tedvîn fì Ahval-i Cibal-i Şervîn, tsh. Mustafa Ahmedzade, (Tahran: İntişarat-i Fikr-i Rûz, 1373), 121; Erdeşir Borzger, Tarihi-i Taberistan, 1: 450-465; Erdoğan Merçil, "Bâvendîler", Türkiye Diyanet Vakfi İslam Ansiklopedisi, c. 5 (İstanbul: TDV Yay., 1992), 214. 
lığının, büyük bir kısmı İspehbediyye kolu ${ }^{14}$ ile alakalıdır. Mekân aralığı ise hanedanın yegâne güç sahası olan Taberistan bölgesidir.

Bâvendîlerin İspehbediyye kolu Sârî merkezli olmak üzere Gilan, Rey ve Kumis'e kadar yani Taberistan sınırlarını da aşarak hüküm sürmüştür. Bu sebeple bölgede hâkimiyet kurmaya çalışan Selçuklu çatışma sahasını kapsamaktadır.

\section{Hüsamü'd-Devle Şehriyâr b. Kârin Dönemi (466-503/1073-1109)}

İspehbediyye kolunun ilk hükümdarı olan Hüsamü’d-Devle Şehriyâr b. Kârin, tahta çıktığında otuz sekiz yaşındaydı. Onun hükümdarlık dönemi Sultan Melikşah (465/1072-485/1092) ve Muhammed Tapar (498/1105511/1118) dönemlerini kapsar. Onun ilk icraatı babası döneminde inşasına başlanılan güvenlik duvarının yükseltilmesini sağlamak oldu. Aynı zamanda sınır birliklerinin sayısını arttırarak kara güvenliğini bir üst seviyeye çıkardı. Bundan başka hızlı bir şekilde Taberistan'ın kuzey ve dağlık kesimlerini Bâvendî hâkimiyet sahasına dâhil ederek 486/1093'de Sârî'yi ele geçirip başkent yaptı. Olası işgal ve kıtlık durumuna karşı Fîrîm ve Âram'daki dağlık şehirleri sığınak ve zahire ambarı haline getirdi. ${ }^{15}$

Selçuklu taht mücadelelerine zaman zaman Bâvendîlerin de müdahil olduğu ifade edilebilir. Bu sebeple Berkyaruk'un (485-1092-497-1104) kardeşi Muhammed Tapar ile taht mücadelesinde topladığ Taberistan askerleri de bulunmaktayd $1 .{ }^{16}$

Muhammed Tapar döneminde İsmailîlerin sığınak merkezlerinden olan Taberistan bölgesinin Bâtınîlerden arındırılması için Bâvendîler ile irtibata geçildiği görülmektedir. Bu bağlamda Muhammed Tapar, 500/1106'da

14 Bâvendîlerin bu şubesinde hükümdarlar sırasıyla şu şekildedir: Hüsamü'd-Devle Şehriyâr b. Kârin (466-503/1073-1109), Necmüddevle Kârîn b. Şehriyâr (503509/1109-1115), Fahrü'l-Mülk Rüstem b. Kârin (509-511/1115-1117), Alâu’dDevle Ali b. Şehriyâr (511-536/1117-1141), Nasırü'd-Devle Şah Gazi Rüstem (536558/1141-1163), Alâu’d-Devle Hasan b. Rüstem (558-567/1163-1173), Hüsamü'dDevle Erdeşîr (567-602/1173-1205), Şemsü'l-Mülk Şah Gazi (602-606/1205-1209). (Erdeşîr Borzger, Tarihi-i Taberistan, 2: 467-537).

15 İbn İsfendiyar, Tarih-i Taberistan, 2: 29-30; Erdeşîr Borzger, Tarihi-i Taberistan, 2: 467.

16 Osman Turan, Selçuklular Tarihî ve Türk-İslam Medeniyeti, (İstanbul: Ötüken Yayınları, 2009), 229. 
Bâvendî lideri Hüsamü'd-Devle b. Kârin'e Bâtınîleri imha etmek için işbirliği teklif etti. Hüsamü'd-Devle Şehriyâr'a gönderilen elçinin mesaj1 şu şekildeydi: "Saltanat makamına hizmet ve saygı gerekir. Şayet bunun hilafina hareket edilmezse mükâfatının alınacă̆ l kesinlikle bilinmelidir." Hüsamü'd-Devle ise bu elçiye "Beni saltanat makamina böyle bir mesaj ile sayg göstermeye layık göremezsiniz..." diyerek karş1lı vermiştir. ${ }^{17}$ Muhammed Tapar'nn teklifi sert bir üslupla iletildiği gerekçesiyle, Hüsamü'd-Devle tarafından aynı sertlikte reddedilince Sultan, Emir Sungur komutasında beş bin süvariyi Taberistan'a yollamakla beraber Rûyan ve Amûl'deki valilere de Sungur ile ortak hareket etmeleri talimatını gönderdi. Sungur, Âmul'de ileri gelenlerce karşılandı. Yapılan istişare sonucu sahil yolundan Sârî'ye gidilmesi kararlaştırıldı. Bu arada, olan bitenden haberi olan Hüsamü'd-Devle, kale onarımı ve gerekli diğer hazırlıkların tamamlanması için hızla harekete geçerek Sârî’ye doğru yola koyuldu. Taberistan'ın eski hanedanlarından Ğârenvendîlerin (غارنوندى) bakiyelerinden İspehbud Mehdî Lapurî, Sârî'de hendek kazarak siper aldı. İki taraf arasında vuku bulan savaşı kaybeden Sungur önce Gürgan'a oradan da Isfahan'a döndü. Bu yenilgi sonrasında Sungur'un Muhammed Tapar'a savaş yoluyla bölgede egemenlik kurulamayacağı yönünde görüşünü belirtmesiyle savaş siyasetinden vazgeçildi. Sultan, savaş yerine meseleyi siyasetle çözme yoluna giderek Hüsamü'd-Devle'ye bir elçi yolladı. Emir Sungur'un talimatların dışına çıktığını belirterek, ondan oğullarından birini Isfahan'a, kendi yanına göndermesini istedi. Sultandan yeminli taahhüt alan Hüsamü'd-Devle, küçük oğlu Alâü'd-Devle Ali'yi sultana yolladı. Bin süvari ve iki bin piyade ile Isfahan'a giden Alâü'd-Devle Ali, Sultan tarafından gayet iyi karşılandı. Sultanın amacı akrabalık tesis etmek olduğundan büyük oğul Necmü'd-Devle'nin rızasının alınması yönünde bir karara varıldı ve Alâü'd-Devle Ali Taberistan'a yollandı. Bâvendî liderinin büyük oğlu Necmü'd-Devle, Muhammed Tapar'in huzuruna vararak sultanın kız kardeşiyle evlendirildi. Böylece Bâvendîler ile Selçuklular arasında takriben 500/1106 yılında akrabalık kuruldu. ${ }^{18}$

Alâü'd-Devle Ali'nin Muhammed Tapar'in huzurunda bir müddet kalarak itibar elde ettiği görülmektedir. Bu durum Bâvendî tahtını elde etmeye

\footnotetext{
17 Muhammed Hasan Han İtimadü's-Saltana, et-Tedvîn fí Ahval-i Cibal-i Şervîn, 132.

18 İbn İsfendiyar, Tarih-i Taberistan, 2: 35-36; Erdeşîr Borzger, Tarihi-i Taberistan, 2: 468-469; Abdülkerim Özaydın, Sultan Muhammed Tapar Devri Selçuklu Tarihi, (Ankara: TTK Yayınları, 1990), 86-88.
} 
çalışan Necmüddevle'yi rahatsız etmiş olmalı ki iki kardeş arasında bu olaydan sonra anlaşmazlık meydana gelmiştir. Ayrıca kaynă̆ımız, Alâü'dDevle'nin babası nezdinde abisine göre daha bilgili ve saygıdeğer kabul edilmesini bu anlaşmazlığın nedenlerinden biri olarak zikreder. Nihayetinde Ali, babası Hüsamü'd-Devle'den müsaade isteyerek annesine ait olan Mîrûneâbâd (ميرونه آباد) köyüne yerleşmiştir. ${ }^{19}$ Bu arada Alâü'd-Devle Ali, Mîrûneâbâd'a yerleşmeden önce Bağdat'a Sultan Muhammed Tapar'ın huzuruna giderek bir süre burada ikamet ettikten sonra Isfahan'da Sultan'in hizmetinde bulunmuştur. Bu sırada Sultan Muhammed Tapar, kız kardeşiyle onu evlendirerek Bâvendîler ile ikinci defa akrabalık bağı kurmuştur. EtTedvîn fì Ahval-i Cibal-i Şervîn adlı eserde belirtildiği üzere Muhammed Tapar tarafindan ziyadesiyle hürmet gören Alâü'd-Devle Ali'nin Bağdat'ta veya Isfahan'da iken tam olarak hangi görevi üstlendiği bilinmemektedir. Ancak misafir gibi yaşamadığını söylemek mümkündür. ${ }^{20}$

Bundan sonra gelişen olaylar Necmüddevle'nin Bâvendî tahtını ele geçirmeye yönelik adımları olarak ifade edilebilir. Zira Alâü'd-Devle Ali'nin Mîrûneâbâd'a yerleşmesinden sonra Necmü'd-Devle Kârin, babasına bask1 yaparak hutbe ve sikkenin kendi adına icra edilmesini talep etmiştir. Bununla beraber babasının hükümdarlığına hürmet göstermediği gibi hükümet işlerini uhdesine almaya ve daha fazla söz sahibi olmaya başlayan Necmü'd-Devle'ye karşı Hüsamü'd-Devle yaşlılığın da etkisiyle etkisiz kalmaya başlamıştır. ${ }^{21} \mathrm{Bu}$ sebeple yetmiş beş yaşına gelen Hüsamü'dDevle tahtından feragat ederek Âmul'e yerleşti. Bâvendî tahtının idaresini de vekâleten büyük oğlu Necmü'd-Devle Kârin'e bırakmak zorunda kaldı. Bütün bunlara rağmen babasına sürekli bask1 yaparak onu adeta tahttan uzaklaştıran Necmü'd-Devle onu tekrar başkente geri getirmek için uğraş vermeye başlamıştır. Bu bağlamda Necmü'd-Devle'nin baskılarına dayanamayan Hüsamü'd-Devle, Rudser (رودسر)'e yerleşmesine rağmen Kârin, babasını ikna edip Sârî'ye geri getirmeyi başarmıştır. Ancak Bâvendîlerin liderliğini vekâleten de olsa Necmü'd-Devle Kârin sürdürmeye devam etmiştir. ${ }^{22}$ Her ne kadar Necmü'd-Devle Kârin'in Bâvendî iktidar1 1109'da başlamış olsa da babası üzerinde kurduğu tahakküm ve kardeşi Alâü'd-

\footnotetext{
19 Erdeşîr Borzger, Tarihi-i Taberistan, 2: 469.

20 İtimadü's-Saltana, et-Tedvîn fî Ahval-i Cibal-i Şervîn, 136.

21 İtimadü's-Saltana, et-Tedvîn fí Ahval-i Cibal-i Şervîn, 137.

22 Erdeşîr Borzger, Tarihi-i Taberistan, 2: 469-470.
} 
Devle Ali'nin Muhammed Tapar'ın kendisine kız kardeşini verme teklifine abisinin daha münasip olduğunu belirtmesi onun fiili iktidarının daha önce başladığına işaret eder. Tam bir tarih belirtmek isabetli olmasa da en azından 500/1106 y1lında yaşanan gelişmelerden hareketle bu tarih veya birkaç y1l öncesinden Necmü'd-Devle Kârin, Bâvendî iktidarında etkin olmaya başlamıştır. Bundan başka babasının başkentten başka bir yerde bulunmasina müsaade etmemesine dikkat çekmek gerekir. Burada kanaatimizce kendisine küskün ve kırgın olan Hüsamü'd-Devle'nin kontrol altında tutulması amaçlanmıştır. Zira Alâü'd-Devle Ali pekâlâ bu durumu babasının imtiyazı üzerinden kullanarak Bâvendî tahtını ele geçirebilirdi. Hüsamü'dDevle'nin daha hayatta iken oğlu tarafindan bu şekilde dışlanması ve küstürülmesi, Bâvendî ileri gelenlerinin desteğinin yitirmesine neden olacak bir durumdu. Netice itibariyle hedeflenen gaye, iktidarın kontrolünü tamamen ele geçirmek ve bunu sürdürmektir.

Melikşah döneminde dostane ve sakin geçen münasebetler, Muhammed Tapar döneminde sıhriyet bağı kurmakla beraber inişli çıkışlı bir seyir takip etti. Sultan Muhammed Tapar, 503/1109'da oğlu Ahmet'i Emir Sungur-u Kuçek (Sungurçe) ile beraber Rey'e yollayarak Aveh, Save, Kumis ve bütün Taberistan'ın idaresini tevdi etti. Ahmet'in naibi olan Sungurçe bu atamanın yerel idareciler nezdinde ilanı ve onların itaati için yerel hanedanlara görevliler gönderdi. Necmü'd-Devle Kârin bu çağrıya olumsuz yanıt verince Sungurçe onu cezalandırmak üzere harekete geçti. Bu bağlamda Alâü'd-Devle Ali'yi Mîrûneâbâd'dan Rey'e getirterek Taberistan'a müdahale etmek için hazırlık yaptı. Ancak bu sırada tüm olan bitenden haberdar olan Hüsamü'd-Devle Şehriyâr, duruma müdahale ederek iki kardeşin olası savaşını önledi. Öte yandan Ahmet, bilinmeyen bir sebepten Rey'de öldü. Hemen ardından Sungurçe de İsmâilîler tarafından öldürüldü. ${ }^{23}$ Bu olaylar gerçekleşirken Necmü'd-Devle Kârin, Sultan Muhammed Tapar'a kardeşini şikâyet etmişti. Bu sebeple Muhammed Tapar, bir emirini iki kardeş arasinda sulh yapmak üzere gönderdi. Ancak sulha yanaşmayan Alâü'd-Devle Ali, Horasan'a Sencer'in yanına gidererek kendisini Bâvendî lideri yapmasını talep etti. ${ }^{24} \mathrm{Bu}$ sırada Karahıtaylı Mahmud'un Maveraünnehir'deki faaliyetleri nedeniyle Sencer bu isteğe kayıtsız kald1. ${ }^{25}$ Fakat Alâü'd-Devle

\footnotetext{
23 İbn İsfendiyar, Tarih-i Taberistan, 2: 39-40.

24 İtimadü's-Saltana, et-Tedvîn fî Ahval-i Cibal-i Şervîn, s. 138.

25 Erdeşîr Borzger, Tarihi-i Taberistan, 2: 471.
} 
Ali, Sencer'e Karahıtaylı Mahmud ile yaptığı savaşta yardım ederek sadakatini göstermekle beraber savaştan sonra Sencer'in maiyyetinde Merv'e geri döndü. ${ }^{26}$

503/1109'da İspehbud Hüsamü'd-Devle Şehriyâr, Temişe'deki isyanı önlemek için uğraşırken vefat etti. Böylece Necmü'd-Devle Kârin vekâleten yürüttüğü Bâvendî liderliğini tek başına uhdesine ald1. ${ }^{27}$ Hüsamü'd-Devle Erdeşîr, kaynaklarda ileri görüşlü, kemal ve akıl sahibi bir kişilik olarak tanıtılmaktadır. Bu sebeple ona Emir Zahir de denilmekteydi. ${ }^{28}$ Sultan Melikşah ile iyi geçinerek makamını korumayı başarmıştır. ${ }^{29}$ Öyle ki Maraşî’nin belirttiğine göre Melikşah, Hüsamü'd-Devle'ye “peder" diye hitap etmekteydi. ${ }^{30}$

\section{Necmü'd-Devle Kârin Dönemi (503-509/1109-1115)}

Erdeşîr Borzger'in Tarihi-i Taberistan adlı eserinde Necmü'd-Devle Kârin'in uzun süreden beri hasta olduğu ve zayıf tabiatlı olduğu için iktidarı elinde uzun soluklu tutamayacak kadar güçsüz olduğu özelikle belirtmektedir. Muhtemelen bu durumun etkisiyle kendi oğlunu dahi zindana attırmaktan çekinmemiştir. Olası bir muhalefetin önüne geçmek için her türlü tedbiri aldığg görülmektedir. Buna rağmen vefatından önce ileri gelenler ile istişare yaparak oğlu Rüstem'in tahta çıkarılması hususunda söz almıştır. ${ }^{31}$ Saltanatı ele geçirmek için yaptıkları düşünüldüğünde böyle bir tedbiri alması, Bâvendî tahtında iddiasını sürekli bir şekilde sürdürmekte olan kardeşi Alâü'd-Devle Ali'nin harekete geçmekten imtina etmeyeceğini bilmesinden ileri gelmekteydi. Onu saf dışı bırakmak ve saltanatın kendi ailesinden devamını sağlamak için böyle bir girişimde bulunmuştu.

\footnotetext{
26 İtimadü's-Saltana, et-Tedvîn fì Ahval-i Cibal-i Şervîn, 138.

27 İbn İsfendiyar, Tarih-i Taberistan, 2: 42.

28 İtimadü's-Saltana, et-Tedvîn fî Ahval-i Cibal-i Şervîn, 131.

29 İbrahim Kafesoğlu, Sultan Melikşah Devrinde Büyük Selçuklu İmparatorluğu, (İstanbul: Ötüken Yayınları, 2014), 140.

30 Seyyid Zahirüddin b. Seyyid Nasirüddin Maraşî, Tarih-i Taberistan Rûyan ve Mâzenderân, tsh. Muhammed Hüseyin Tesbihi, (Tahran: Müessese-i Matbuat-i Şarki, 1345), 32 .

31 Erdeşîr Borzger, Tarihi-i Taberistan, 2: 472.
} 
İtimadü's-Saltana'da bu hususta şöyle bir bilgi bulunmaktadır: Necmü'dDevle Kârin vefat etmeden kısa bir süre önce Alâü'd-Devle Ali'nin Bâvendî iktidarını ele geçirmesini önlemek için oğlu Rüstem'e bir takım telkinlerde bulunmuştur. Buna göre: Alâü'd-Devle Ali'nin Horasan'da olmadığı haberini alırsa kesinlikle hazırlıklı olmasını, amcası Alâü'd-Devle Ali, halkın teveccühünü kazanırsa kendisi adına işlerin zorlaşacağını belirtmiştir. Bu sebeple vefatı halinde Şehriyârkûh'a ulaşana kadar bunun gizlenmesi ve derhal ahalinin itaatinin alınmasını istemiştir. ${ }^{32}$

Nitekim Necmü'd-Devle Kârin'in hükümdarlığı fazla uzun sürmedi. Onun vefatından sonra Bâvendî ileri gelenleri aralarında münazara yaparak Rüstem'i gizlice tahta çıkardılar. Sabık hükümdar Necmü'd-Devle'nin toprağa verilmesi de oldukça gizli bir şekilde yapılmıştı. ${ }^{33}$

İspehbud Rüstem Fahrü'l-Mülk, Bâvendî tahtına oturduktan sonra başta amcası Alâü'd-Devle Ali olmak üzere diğer yerel idareci ve hanedan mensuplarından yana oldukça endişe verici bir ortam ile karşı karşıyaydı. Zira amcaları Yezgiderd ve Behram'ın yanı sıra babası Necmü'd-Devle Kârin tarafından gözleri kör edilen Rüstem Dabu-yi Âmulî, iktidarına karşı hazır bekleyen tehlikelerdi. En büyük tehdit amcası Alâü'd-Devle Ali, bu sırada Sencer'in yanında Horasan'daydı. Şehriyârkûh ileri gelenleri onu taht değişikliği konusunda haberdar etmelerine rağmen Sencer, hasta olduğu için yanından ayrılamadı. Bir süre zaman kazanan Rüstem, Alâü'd-Devle Ali'nin olası müdahalesine karşılık derhal Isfahan'a mektup gönderdi ve Muhammed Tapar'dan yardım talebinde bulundu. ${ }^{34} \mathrm{Bu}$ arada amcasına bir elçi nezdinde mektup göndererek şu mesajı iletmişti: "Mülk ve vilayetler babamındı. Ben onun veliahtı oldum. Bu suretle hükümdarlığa getirildim. " ${ }^{35}$ Rüstem, Bâvendî tahtında gasıp konumda olmadığını, usul ve esasa uygun bir şekilde hükümdar olduğunu amcasına kabul ettirmeye çalışmaktadır. Bu sayede onun taht iddiasından vazgeçirmek istemektedir.

Rüstem, tahtını sağlama almak ve çevresindeki taht iddiacılarını saf dışı bırakmak için Muhammed Tapar'dan yardım isteyince Ebu Nasır Şerabî Taberistan'a gönderilmiştir. Öte yandan iyileșen Sencer'in Alâü'd-

\footnotetext{
32 İtimadü's-Saltana, et-Tedvîn fî Ahval-i Cibal-i Şervîn, 139.

33 İbn İsfendiyar, Tarih-i Taberistan, 2: 43; Erdeşîr Borzger, Tarihi-i Taberistan, 2: 472.

34 Erdeşîr Borzger, Tarihi-i Taberistan, 2: 472-473.

35 İtimadü's-Saltana, et-Tedvîn fî Ahval-i Cibal-i Şervîn, 139-140.
} 
Devle Ali’yi Mirûneâbâd'a geri gönderdiğini belirtmek gerekir. Şerabî, Taberistan'a ulaştığında Alâü'd-Devle Ali'yi beraberinde Isfahan'a götürmüş ancak Fahrü'l-Mülk Rüstem, bu çağrıya kayıtsız kalmıştır. Rüstem'in bu tavrının, Muhammed Tapar nezdinde sert bir şekilde karşllk bulduğunu görmekteyiz. Zira Mengüberzu (منكوبرزو) ve Yarguş Arğun (يرغشارغون) Rüstem'i cezalandırmak üzere gönderilmiştir. Rüstem'in uzlaşmaz tavrı sonunu getirmiş, çok geçmeden hastalanarak 511/1117'de ölmüştür. ${ }^{36}$ Sadece iki yıl Bâvendî tahtında hüküm süren Rüstem'in iktidarı tabiri caizse amcası Alâü'd-Devle'nin gölgesinde geçmiştir. Onun saltanatının uzun soluklu olmayışında Alâü'd-Devle'nin Büyük Selçuklu saltanatı ile olan ikili münasebetlerinin belli bir hukuka dayanması ve Rüstem'in tecrübesizliğinin ziyadesiyle etkili olduğu görülmektedir.

Rüstem'in ölümü sonras1 Alâü'd-Devle Ali serbest bırakılmasına rağmen henüz Isfahan'da Sultan Muhammed Tapar'in gözetiminde bulunuyordu. Dolayısıyla henüz Bâvendî tahtında belirsizlik mevcuttu. Zira hanedan soyundan olan Behram ve Feramurz Taberistan'da çatışma içinde iktidarı elde etmeye çalışıyorlardı. Bu bağlamda önce Ali'nin küçük kardeşi Behram, Sârî'ye gelerek başkentte hâkimiyeti ele geçirdi. Daha sonra Rüstem'in oğlu Feramurz Bâvendî tahtı için mücadeleye girişti. Bu gelişmeler yaşanırken Bâvendî ileri gelenlerinden bir heyet, Tapar'ın huzuruna vararak müdahale edilmesini talep ettiler. Bu talebe karşıllk Sultan, Mengüberzu ve Kadı Rükneddin Bezzâzi'yi Taberistan'a yolladı. Bu arada her iki Bâvendî taht iddiacısı savaş hazırlıklarını yapmıştı. Emir Mengüberzu'ya Ğârenvendîlerden Mehdi Lapurî de yardım edince Selçuklu merkezinden yapılan bu müdahale başarılı oldu. Bu olaydan sonra Bâvendî tahtında sükûnetin sağlanılması için Selçuklu nezdinde sadakatini defalarca ispatlamış olan Alâü'd-Devle Ali, Yarguş Arğun ile beraber Taberistan'a gönderildi. ${ }^{37}$ Metbu devlet için hiç şüphesiz sadakat belirleyici unsur olarak ön plana çıkar. Bâvendî tahtı için de Selçukluların bu durumu gözettiği görülmektedir. Hüsamü'd-Devle Şehriyâr'in ölümü (503/1109) sonras1 Bâvendîlerde meydana gelen istikrarsızlık henüz kesin bir çözüme kavuş-

36 İbn İsfendiyar, Tarih-i Taberistan, 2: 44-46; Erdeşîr Borzger, Tarihi-i Taberistan, 2: 473-474.

37 İbn İsfendiyar, Tarih-i Taberistan, 2: 46-48; İtimadü's-Saltana, et-Tedvîn fî Ahval-i Cibal-i Şervîn, 141-142; Erdeşîr Borzger, Tarihi-i Taberistan, 2: 475. 
turulmasa da kısmi bir düzen sağlanmıştır.

$\mathrm{Bu}$ arada Muhammed Tapar'ın ölüm haberi üzerine Mengüberzu derhal Isfahan'a dönmüş, Büyük Selçuklu tahtına Sultan Mahmud geçmiştir. Bunun üzerine Alâü'd-Devle Ali, Sultan Mahmud ile uzun süre Isfahan'da ikamet ettiği için aralarındaki hukuka binaen Isfahan'a sultanın huzuruna onu tebrik etmeye gitmiştir. ${ }^{38}$ Alâü'd-Devle Ali, Isfahan'dayken Sultan Mahmud, babası ile Alâü'd-Devle Ali'nin arasının iyi olmadığını ancak bunu telafi ederek ilişkileri düzleteceğini belirten birkaç söz sarf etmiştir. Bu bağlamda ikili münasebetlerin bundan sonra barışçıl ve dostane geçeceğini söylemek mümkündür. ${ }^{39}$

\section{Alâü’d-Devle Ali Dönemi (511-536/1117-1141)}

Alâü'd-Devle Ali, iktidarı ele geçirmesine rağmen kardeşi Behram'ın varlığ tehdit unsuru olarak devam etmekteydi. Zira henüz bertaraf edilmeyen Behram, 512/1118'de Bâvendî tahtını ele geçirmek için yeni bir girişimde bulundu. Ancak Behram, karşısındaki müttefik güçlere nazaran zayıf kaldığ için mağlup oldu. Zira Rüstem'in oğlu Feramurz ve Ğârenvendilerden Emir İshak Tapurî’nin İspehbud Ali’ye destek verdiği iki bin kişilik bir askerî kuvvet ile savaşmışı. Rüstem bu mağlubiyet sonrası Sultan Mahmud'un yanına sığınınca Alâü'd-Devle Ali, kesin olarak Bâvendî tahtına oturdu. Ancak aynı yılın ortalarında yaşanan gelişmeler Alâü'd-Devle Ali'yi tekrar zor durumda bıraktı. Bu defa metbu devlet Selçuklularda taht sorunu baş göstermişti. Horasan hâkimi Sencer'in ordu komutanı Emir Üner ve Sultan Mahmud'un komutanı Emir Ali Bâr Gürgan'da Büyük Selçuklu tahtı için savaştıklarında Alâü'd-Devle Ali, Emir Ali Bâr'dan yani Sultan Mahmud'dan yana tavır aldı. Buna rağmen Emir Ali Bâr, Rüstem' in oğlu Feramurz'u da kendi tarafına çekerek Behram ile beraber Taberistan'1 ele geçirmek için Bâvendîler üzerine yürüdü. Temişe'de birleşen müttefik kuvvetler kısa sürede Sârî'ye gelerek Bâvendî başkentini işgal etti. Bu olay sonrası Alâü'd-Devle Ali daha korunaklı olan Firim'e sığınmak zorunda kald1. ${ }^{40}$

38 İbn İsfendiyar, Tarih-i Taberistan, 2: 48-49.

39 İtimadü's-Saltana, et-Tedvîn fî Ahval-i Cibal-i Şervîn, 142.

40 İbn İsfendiyar, Tarih-i Taberistan, 2: 52-53; Erdeşîr Borzger, Tarihi-i Taberistan, 2 : 476-479. 
Ancak Emir Ali Bâr Taberistan'da uzun süre kalmadığ 1 için Behram ve Feramurz da bir noktada hamisiz kaldılar. Rey'e Sultan Mahmud'un yanına sığınan bu iki taht iddiacısına dair sorunu çözmek üzere İspehbud Alâü'd-Devle Ali ise Sultan Mahmud'dan arabuluculuk yapması için ricada bulunmak üzere Rey'e gitti. Onun gelişiyle hanedan mensupları Behram ve Feramurz Kisliyan (كيسليان) kalesine gönderildiler ve İspehbud Ali, Rey'den ayrılana kadar burada kaldılar. Bir süre sonra ise Horasan'a Sencer'in yanına gittiler. ${ }^{41} \mathrm{Bu}$ sirada Sultan Mahmud ile Sencer arasında taht mücadelesi yaşandığı için Bâvendîlerin iç mücadeleleri Selçuklular nazarında pek te önem arz etmiyordu. Dolayısıyla Sultan Mahmud, Behram ve Feramurz için istediklerini alabileceği yararlı bir kapı değildi. Bu sebeple onlar Sencer'den yardım istemek üzere Rey'den ayrılmışlardı. Öte yandan Alâü'd-Devle Ali ile Sultan Mahmud arasında eskiden kalma bir hukuk olduğu için onun Bâvendî tahtında bulunması Mahmud'un isteyebileceği bir durumdu. Bu sebeple olsa gerek, onun Rey'e gelişiyle olası problemli bir durum yaşanmaması için İspehbud Ali'nin muhalifleri Rey'den çıkarılmıştır.

Alâü'd-Devle Ali bu sorunu çözmüş olsa da bu defa Selçukluların yeni sultanı Sencer'in uzun süre sürecek olan hışmına uğrayacaktı. 513/1119 yılında gerçekleşen Selçuklu taht mücadelesinde Sencer'in yardım talebine Sultan Mahmud'dan yana tavir alarak cevap veren ve bununla beraber bu mücadeleye katılmayan Alâü'd-Devle Ali, Sultan Sencer (1118-1157) tarafından Horasan'a çağırdı. Bu çağrıya karşılık hastalığını bahane ederek oğlu Şah Gazi Rüstem'i yanında Bâvendî ileri gelenlerinden bir heyet ile beraber Sencer'in huzuruna yolladi. Bu heyet dört ay boyunca Sencer'in huzurunda kaldı. Bu sırada Selçuklu başkenti Merv'de bulunan Behram, Alâü'd-Devle Ali aleyhine yaptığı propagandanın meyvelerini alarak Bâvendî tahtını uhdesine alan bir ferman ve Muhammed Cuşi önderliğinde bir grup askerle Taberistan'a doğru yola koyulmayı başarmıştı. Gelişmelerden haberdar olan Alâü'd-Devle Ali ise Taberistan yerel güçlerinin büyük bir kısmının Behram'dan yana tavır aldığı ağır şartlarda Temişe'de savaş hazırlıklarını yapmıştı. Temişe'yi Horasan kuvvetlerine karşı otuz sekiz gün boyunca savunan şehir muhafızı İspehbud Rüstem Dârâ, daha fazla dayanamayınca şehir Behram'ın eline geçti. Buna rağmen pes etme-

${ }^{41}$ Erdeşîr Borzger, Tarihi-i Taberistan, 2: 480; İbn İsfendiyar, Tarih-i Taberistan, 2: 55. 
yen İspehbud Ali, oğlu Şah Gazi Rüstem aracıllğıyla Şehriyârkûh'u aldıktan sonra Gürgan kapısında Cuşi ile yaptığı savaşı kazanarak müttefik güçleri topraklarından uzaklaştırdı ${ }^{42}$ Firar eden Cuşi'nin ordusunu takip eden Bâvendî kuvvetleri onlardan birçoğunu öldürerek kesin bir zafer kazanmakla beraber ${ }^{43}$ çok geçmeden sürekli Bâvendî tahtı için sorun teşkil eden Behram'ı da Gürgan'daki ikametgâhında öldürerek bu tehdidi de ortadan kaldırmış oldular. ${ }^{44}$

İspehbud Ali, tahtına karşı oluşan muhalif ortamı şimdilik bertaraf ederek Taberistan'ın tamamına kendi içinde bağımsız bir güç olarak hâkim olmayı başarmışt1. ${ }^{45}$ Fakat kendisi için esas sorun, hükümdarlığ süresince devam edecek olan Sencer'in 1srarlı tutumuydu. Bu bağlamda Sultan Sencer, batı işlerini düzene sokmak için Rey'e geldiğinde İspehbud'u itaatinden emin olmak için bir kez daha huzuruna davet etti. İspehbud Ali'nin Rey yolundayken kararından vazgeçip geri dönmesine oldukça hiddetlenen Sultan Sencer, yeğeni Mesud'u Taberistan'a yollayarak onu cezalandırmak istedi. Ancak Bâvendîler diplomatik girişimle Mesud'u Kerdâbâd (كردآباد) mevkiinde değerli birç̧ok hediye ile onu karşılayıp üç gün boyunca burada ağırladı. İspehbud Ali’nin oğlu Şah Gazi Rüstem öncülügündeki bu heyet ile beraber başkent Sârî'ye geçildi. Burada bir ay müddetle ikamet eden Mesud, değerli hediyeler ile geri döndü. Daha sonra bu hediyeler Sencer'e sunulmak üzere Horasan'a gönderildi. ${ }^{46}$ İspehbud Ali, haklı olarak açık bir savaş yapmaktan imtina etmekteydi. Zira uzun süre saltanat makamında ikamet ettiği için Selçukluların gücünü bizzat müşahede etme imkânı bulmuştu. Bununda beraber huzura varmanın kendisi açısından meydana getirecek sakıncalarını da tahmin ettiği için durumu bir şekilde geçiştirmeye çalışmaktadır. Bu tavrında daha önceki tecrübelerinin ziyadesiyle etkili olduğunu önemle belirtmek gerekir. Zira o uzun süre hem Sencer'in hem de Muhammed Tapar'ın yanında kalmış ve Bâvendî tahtına oturma arzusunu bir süreliğine tehir etmişti. Tekrar aynı durumu yaşamamak için bizzat huzura gitmiyordu. Ancak olası bir savaş durumundan kaçınmak için de elinden geleni yapıyordu. Bu bağlamda huzura oğlunun içinde bulundu-

\footnotetext{
42 İbn İsfendiyar, Tarih-i Taberistan, 2: 56-61.

43 İtimadü's-Saltana, et-Tedvîn fî Ahval-i Cibal-i Şervîn, 148.

44 Erdeşîr Borzger, Tarihi-i Taberistan, 2: 482.

45 İtimadü's-Saltana, et-Tedvîn fî Ahval-i Cibal-i Şervîn, 148.

46 Erdeşir Borzger, Tarihi-i Taberistan, 2: 483.
} 
ğu bir heyet yollayarak ya da Taberistan'a bizzat gelen Selçuklu hanedan mensubunu oldukça iyi karşılayıp değerli hediyeler ile uğurluyordu. Zira Bâvendîler olası bir husumette her ne kadar coğrafi şartlar nedeniyle avantajlı olsalar da Selçuklu kuvvetlerine karşı savaşı göze alamazlardı.

Mesud, Horasan'a ulaşıp Bâvendîlerin itaatini almasına rağmen Sultan Sencer, İspehbud Ali'ye güven duymadığı için Taberistan'a müdahale etme arzusunu hiçbir zaman sonlandırmadı. Bu kez sorunu kökten çözmek için emirlerinden Arguş'u Bâvendîler üzerine yolladı. İspehbud Ali bunun üzerine Temişe'de konuşlanarak altı ay boyunca Selçuklu kuvvetlerine geçit vermedi. Arguş geri dönmek zorunda kaldı. Bu olaydan kısa bir süre sonra Sencer'in komutanlarından Çavlı, Âmul sınırları dâhilinde bulunan Dârâ kalesini sultanın mülkü sayarak idaresi altına aldı. İspehbud Ali, kaleyi geri alınca Çavlı tekrar güç toplamak için Âmul'e geldi. Kucur, Rûyân Lârican ve Çulâb askerlerinin desteğine rağmen Çavlı yenilerek Rey'e geri döndü. Sencer'in İspehbud Ali 1srar1 521/1127 y1lında da devam etti. Tekrar Horasan'a çağırılmasına rağmen olumsuz yanıt verince Sultan Mesud, Sencer adına Gürgan'a geldi. Buradan Temişe'ye ulaşarak şehri hâkimiyeti altına aldı. Ancak bu kısa sürdü ve İspehbud Ali şehri geri aldı. Bâvendîler ile Selçuklular arasında bu kez diplomatik çözüm yerine savaş gerçekleşti. Şah Gazi Rüstem'in kalabalık bir ordu ile babasına yardım etmesi sonucu Mesud'un ordusu dağıldı. Çavlı bu savaşta öldürülürken, Mesud, Gürgan'a çekildi. Bu olay sonrası Sencer yeniden Arguş’u Bâvendîler üzerine yolladı. Sekiz aylık bir mücadelenin ardından Selçuklu kuvvetleri bir sonuç elde edemeden geri döndü. ${ }^{47}$ Bâvendîler üzerine kısa aralıklarla dört kez sefer tertip edilmesi, Sencer' in bu konudaki 1srarlı tutumunu gösterir. Ayn1 zamanda Bâvendîlerin topraklarını coğrafi şartlarında da avantajını kullanarak başarılı bir şekilde savunduğunu belirtmek gerekir.

Öte yandan Alâü'd-Devle Ali, Sencer'in müdahil olduğu Irak Selçuklularının taht mücadelelerine 521/1127'de Şah Gazi Rüstem komutasında beş bin kişilik bir kuvvet yollad1. ${ }^{48} \mathrm{Bu}$ arada Gürgan'da bulunan ve Bâvendîlerle savaşmak üzere hazır kıta bekleyen Mesud'un kuvvetleri Sencer'e yardım etmek üzere geri dönmüştü. ${ }^{49}$ Selçuklular ile Taberistan

47 Erdeşîr Borzger, Tarihi-i Taberistan, 2, 484-486.

48 Zahirüddin Maraşî, Tarih-i Taberistan, 101-106; Hakkı Dursun Yıldız, "Harezmşahlar Devleti”, Doğuştan Günümüze Büyük İslam Tarihi, (İstanbul: Çağ Yayınları, 1992), 9: 20.

49 Erdeşîr Borzger, Tarihi-i Taberistan, 2: 486. 
hâkimi olan Bâvendîlerin metbû-tâbi münasebetini anlamak açısından bu olay kayda değerdir.

Bu olaydan kısa bir süre sonra Sultan Sencer ile İspehbud Alâü'd-Devle Ali arasında bir kez daha husumet ortamı meydana geldi. Bu defa mevzu İspehbud'un vefat eden hanımından geriye kalan özel eşyaların Horasan'a nakliydi. Bilindiği üzere İspehbud'un eşi Muhammed Tapar'ın kardeşiydi. Bu sebeple Sencer, hatundan kalma mülkün nakli için gulamlarından bir kaçını Sârî'ye yolladı. Ancak Taberistan'a giden bu heyet eli boş geri dönünce Sencer bu defa ordu komutanlarından Muhammed Kâş̂̀’yi İspehbud'a gönderdi. Bu olay sirasında Bâvendîleri zor duruma sokan Dârâ kalesi isyanı meydana gelince mesele daha fazla uzatılmayarak hatundan kalan mülke karşılık yüz bin dinar ödeme yapıldı ve sorun çözülmüş oldu. İspehbud Ali konusunda istediği sonucu elde edemeyen Sultan Sencer, kısa bir süre sonra Bâvendîler üzerine bir kez daha sefer tertip ederek komutanlarından Abbas'1 Rey'den Taberistan'a yolladı. Abbas, Âmul'e ulaştığında İspehbud Ali de Mamtir'de savaş hazırlıklarına başlamıştı. Ancak savaş yerine diplomatik girişimler yeğlenince Abbas bir süre başkent Sârî'de ağırlandı ve mesele kansız bir şekilde çözüldü. Bu arada İspehbud Ali ile oğlu Rüstem arasında Dârâ kalesi meselesi nedeniyle bir gerginlik meydana gelmiş ancak bu sorun, İspehbud Şehrdâr Cemalü'lMülk'ün girişimleriyle sonlandırılmıştı. ${ }^{50}$

Selçuklu hanedan üyelerinin taht mücadelelerinde askerî destek temini ve yeniden toparlanmak için Taberistan'dan sürekli olarak istifade ettiklerini görüyoruz. Bunlardan biri Tuğrul ve Mesud'un Irak Selçuklu taht mücadelesidir. Tuğrul, Mesud'a yenilince Taberistan'a Alâü'd-Devle Ali'nin yanına kaçmıştır. Alâü'd-Devle Ali, Tuğrul ve maiyetini oldukça iyi karşılamış, Tuğrul kışı Taberistan' da geçirmiştir. ${ }^{51}$

\section{5. Şah Gazi Rüstem Dönemi (536-558/1141-1163)}

536/1141'de İspehbud Alâü'd-Devle Ali, yirmi dört yıllık hükümdarlığının ardından nikris hastalığından ölünce yerine büyük oğlu Rüstem,

50 Erdeşîr Borzger, Tarihi-i Taberistan, 2: 487-488.

51 Ahmed b. Mahmud, Selçukname, haz. Erdoğan Merçil, (İstanbul: Bilge Kültür Sanat Yayınları, 2011), 213-214; Bundarî, Zübdetü'n-Nusra ve Nubhetü'l-Usra, çev. Kivameddin Burslan, (Ankara: TTK Yayınları, 1999), 158; Hüseyin Kayhan, Irak Selçukluları, (Konya: Çizgi Kitapevi Yayınları, 2001), 135-136. 
Bâvendî tahtına geçti. Sert bir tabiata sahip olması nedeniyle ileri gelenler nazarında makul bir hükümdar olmamasına rağmen babası döneminde savaşlarda elde ettiği başarılar ve tecrübeler, onun saltanat makamı için en uygun hanedan mensubu olduğu düşüncesini kabul ettirmektedir. Ancak başka saltanat ortaklarının her zaman ki gibi var olduğunu belirtmek gerekir. Zira tahta geçmesinden kısa bir süre sonra kardeşi Merdaviz'in muhalefetiyle karşı karşıya kalmıştır. Merdaviz, Sultan Sencer'den ald1ğ1 destek ile Selçuklu komutanı Kaştemir'in (قشتمير) on bin kişilik ordusuyla beraber Gürgan'a geldiğinde bu ittifaka Kebûdcâme, (كبودجامد) (كبود) (كبود)

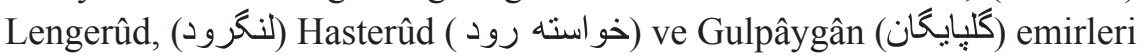

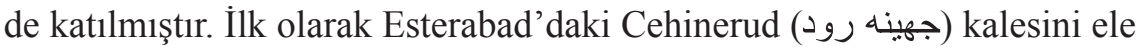
geçiren müttefik güçlere daha sonra Pâdüspanî lideri Üstundar Şehrenveş (شهرنوش) ve diğer bazı yerel emirler de destek vereceklerini bildirmişlerdir. Aleyhine gittikçe genişleyen müttefik cephenin baskısı altında Şah Gazi Rüstem ile Merdaviz arasında küçük çaplı bir çatışma yaşanmış, Rüstem, Dârâ kalesine sığınmıştır. Merdaviz ve Selçuklu kuvvetler ileri harekâtına devam ederek önce Sârî'ye ardından da Âmul'e ulaşmışlardır. Bu arada Dârâ kalesi kuşatmasından önce Rüstem'in oğlu Hasan Alâü'd-Devle'nin idaresinde olan İlâl kalesinin ele geçirildiğini ifade etmek gerekir. Hasan, kaleyi terk ederek Rey'e kaçarken kız kardeşi Türklerin eline esir düşmüştür. Rüstem'i oldukça zor durumda bırakan Dârâ kalesi kuşatması sekiz ay müddetle devam etmiş, 536-537/1141-1142 yıllarında bu kuşatma süresince Taberistan'a yağmur yağmamıştır. Bu olayın bölge ikim şartları açısından olağanüstü bir durum olduğunun altını çizmek gerekir. Zira bu müddet sonunda yağan yağmur bölgede bataklık ve sel meydana getirince Türkler paniğe kapılarak kuşatmayı kaldırmışlardır. Eline geçen firsatı değerlendirmek isteyen Şah Gazi Rüstem, Selçuklu kuvvetlerini Esterâbâd'a kadar takip etmiştir. Bu arada Rey'e kaçan Hasan Alâü'd-Devle, Taberistan'a geri dönmesine rağmen babası tarafından huzura alınmamış, yirmi ay boyunca Kisliyan kalesine hapsedilmiştir. Daha sonra ileri gelenlerin arabuluculuğuyla serbest bırakılmıştır. ${ }^{52}$ Burada çok net bir şekilde coğrafi şartların Bâvendîler lehine avantaj teşkil ettiği görülmektedir. İklim şartlarına yabancı olan Selçukluların ise kuşatmanın uzaması ile doğru orantılı muhtemel psikolojik yıpranma ile karşı karşıya kalmıştır. Zira büyük bir kısmı sarp ve ele geçirilmesi zor mevkilerde bulunan kaleler, kuşatmaların

52 Erdeşîr Borzger, Tarihi-i Taberistan, 2: 488-491. 
uzamasına neden olurken geçen sürede iklime alış1k olmayan harici güçlerin direncini kırmaktaydı.

Selçuklular birçok kez Bâvendîler'den askeri kuvvet temin etmiştir. Sencer döneminde 536/1141 yılında göçebe Karluklulara karşı yapılan savaşta asker temini buna örnektir. Bunun yanında metbu devlet olan Selçukluların Taberistan'a yardıma gittiğini de görüyoruz. Bu bağlamda Taberistan'1 işgal eden Karlukluların Sencer'in karşı koymasıyla bölgeyi terk ettiklerini söyleyebiliriz. ${ }^{53}$ Bununla birlikte Katvan savaşı sonrasında Selçuklu otoritesi zayıfladığı için Taberistan gerçek anlamda bağımsızlığına kavuştu. ${ }^{54}$

Merdaviz'in saltanatı ele geçirme girişimi sonuçsuz kalmış ancak Sultan Sencer'in kız kardeşiyle evli olması ve onun fermanıyla Esterâbâd'da hüküm sürmesi nedeniyle tehlike henüz bitmiş değildi. ${ }^{55}$ Rüstem, Sencer'in esir düşmesiyle savunmasız kalan ve tahtına karşı mütemadiyen sorun teşkil eden kardeşini ortadan kaldırmak için Esterâbâd'a bir suikast timi sevk etti. Muhtemelen başına geleceklerden haberdar olan Merdaviz, aile efradını korunaklı bir mevki olan Kebûdcâme'ye göndermişti. Nihayetinde Rüstem'in gulamları tarafından öldürülünce bu tehdit ortadan kalkmış oldu. $^{56}$

Taberistan bölgesinin coğrafî şartları bozguna uğrayan asi şehzadeler nazarında sığınılacak güvenli bir merkez konumundaydı. Bölgenin bu hususiyeti ile ilgili, Sencer'in esir düşmesi sonrasında hükümdar varisi olan yeğeni Süleyman Şah'ın Taberistan'a kaçmasını örnek verilebiliriz. ${ }^{57}$ Bundan başka özellikle Sencer'in Oğuzlara esir düşmesi sonra yaşanan kargaşa nedeniyle güvenlikli bir mekân arayışı içine giren Selçuklu ileri gelenlerinin birçoğu Bâvendî lideri Şah Gazi Rüstem'e sığındılar. Süleyman Şah'1 oldukça iyi karşılayan ve misafir eden Şah Gazi, buna karşıllık olarak Rey

53 İbnü'l-Esir, el-Kamil fi 't-Tarih, 9: 155-158; Sergey Grigoreviç Agacanov, Selçuklular, çev. Ekber Necef- Ahmed Annaberdiyev, (İstanbul: Ötüken Yayınları, 2006), 270; İbrahim Kafesoğlu, Harezmşahlar Devleti Tarihi, (Ankara: TTK Yayınlar, 2000), 53.

54 Sergey Agacanov, Selçuklular, 283.

55 İbn İsfendiyar, Tarih-i Taberistan, 2: 87.

56 İbn İsfendiyar, Tarih-i Taberistan, 2: 94-95; Erdeşîr Borzger, Tarihi-i Taberistan, 2: 492.

57 Muhammed b. Ali. B. Süleyman er-Râvendî, Râhatü 's-Südûr ve Ayetü's-Sürûr, çev. Ahmed Ateş, (Ankara: TTK Yayınları, 1999), 2: 255; İbn İsfendiyar, Tarih-i Taberistan, 2: 91-92; Yazıcızâde Ali, Tevarih-i Âl-i Selçuk, haz. Abdullah Bakır, (İstanbul: Çamlıca Yayınları, 2009), 120; Sergey Agacanov, Selçuklular, 319-320. 
şehrinin yönetimini uhdesine almıştır. Şehir yaklaşık yirmi ay müddetle Bâvendî hâkimiyetinde kalmıştır. Bununla birlikte Sencer'in esaretinden oldukça iyi istifade eden Şah Gazi Rüstem, Öncelikle Taberistan'da yerel emirleri itaat altına aldı. Ardından bölge dışında hâkimiyet sahasını genişleterek Gürgan ve Câcerm'i Bâvendî topraklarına kattı. Yeni elde ettiği topraklara bir takım atamalar yaptıktan sonra Taberistan'a geri döndü. ${ }^{58}$

$\mathrm{Bu}$ arada Sencer'in ikinci kez esaretten kurtulup (551/1156) tabi hükümdarları huzuruna çağırmasından sonra yaşanan gelişmeler Bâvendîlerin İsmâilîlerle amansız bir mücadele içine girmesine neden oldu. Bu bağlamda Sultan Sencer'in huzuruna itaatini bildirmek üzere giden Şah Gazi Rüstem'in oğlu Gerdbazû (كَردبازو) Bâtıniler tarafından öldürülünce Şah Gazi Rüstem, İsmâilîlere karşı açıktan savaşmaya başladı. Kaynakların belirttiğine göre İsmâilîlerden on sekiz bin kişi yapılan seferlerde öldürdü. ${ }^{59}$ Bundan başka Şah Gazi Rüstem, nüfuzunu arttırmak için kız kardeşini Larican meliki Manuçehr ile evlendirdi. Oğuzların Esterâbâd yakınlarına kadar ulaştığını haber alınca on iki bin askerle Sârî̀ye geri döndü. ${ }^{60}$ Selçukluların yıkılmaya yüz tuttuğu zaman diliminde yaşanan keşmekeş ortamı bazı tedbirlerin alınmasını zorunlu kılmaktaydı. Bu sebeple Şah Gazi Rüstem hazır kıta askeri birlik bulundurmakla beraber Oğuzların veya başkaca unsurların yerel dengelere dayanan Taberistan için bir tehdit oluşturmamasına azami gayret göstermiştir.

Oğuz isyanı sonrası Sultan Sencer'in esir düşmesiyle yeğeni Karahanlı hükümdarı Mahmud Han, Horasan'da sükûneti sağlamak üzere tahta oturtuldu. Bu surada Nişabur'u elinde tutan Sencer'in gulamlarından Müeyyed Ayaba ile barış yaparak beraberce Taberistan'a sefer tertip ettiler. Bâvendî hükümdarı Şah Gazi Rüstem döneminde gerçekleşen bu sefer öncesinde Rüstem savunmada kalmadan taarruza geçti. Bu bağlamda Horasan'daki Selçuklu kıtalarına büyük zarar verildi. Buna karşılık Müeyyed öncülüğündeki Türk kuvvetleri Sârî̀ye doğru ilerlerken Bâvendîler tarafindan pusuya düşürülüp bin kadarı esir alındı. Bu arada Müeyyed az bir kuvvetle canını zor kurtarmıştı. Bu esirlere iyi muamelede bulunan Rüstem, bölgenin karakteristik özelliğini açığa vururcasına Mahmud Han'a şu ha-

58 Erdeşîr Borzger, Tarihi-i Taberistan, 2: 491- 492.

59 İbn İsfendiyar, Tarih-i Taberistan, 2: 87-89; Erdeşîr Borzger, Tarihi-i Taberistan, 2: 492.

60 Erdeşîr Borzger, Tarihi-i Taberistan, 2: 493-494. 
beri yolladı "Bizim halkımız bağımsızdır. Ne yaparlarsa yapsınlar bizim onayımızla yaparlar." Bu olay sonrası Mahmud Han ile anlaşma yapıldı. Buna göre Mahmud Han, Gürgan havalisinden yirmi bin dinar karşılığında çekilecekti. Mahmud Han geri çekildikten sonra muhassillere ödenmesi gereken meblağ, Şah Gazi Rüstem tarafından ödenmedi. Öte yandan Horasan askerleri bu sefer sırasında beslenme sorunu da yaşamışlardı. İbn İsfendiyar'ın belirttiğine göre yeterli miktarda buğday bulamayan Horasan kuvvetleri, bulabildikleri buğday başaklarını kesip yemek zorunda kalmışlardı. ${ }^{61}$ Burada Bâvendîlerin kendilerine duydukları özgüven ön plana çıkmaktadır. Öte yandan sefer sırasında yaşanan beslenme sorunu muhtemelen daha önceki Taberistan seferlerinde de benzer şekillerde meydana gelmiştir. Bu şartlar altında Bâvendîlerin iç dinamiklerini korudukları sürece harici saldırılara bir şekilde karşılık verdiklerini ve varlıklarını koruduklarını söylemek mümkündür.

Bölge coğrafyasını yeterince bilmeyen Horasan kuvvetleri, Taberistan'da kolayca pusuya düşmüş ve zorluk çekmiştir. Bâvendîler hâkim oldukları toprakların çetin coğrafi şartlarından istifade ettikleri sürece durum hep kendi lehlerine gelişmiştir. Bu arada Şah Gazi Rüstem'in Mahmud Han ile yaptığı anlaşma gereği ödemesi gereken meblağı reddetmesi hem şahsında hanedanlığını kuvvetli görmesi hem de değişen şartlar nedeniyle hâkimiyet sahaları için ciddi bir tehdidin olmayışı ile izah edilebilir. Zira Taberistan sınırında bir tarafta Irak Selçuklularında yaşanan taht mücadeleleri, öte tarafta ise organize bir teşkilattan yoksun birkaç güçlü beyin etrafında özellikle Horasan' da yağma yapan Oğuzların tahribatları, mukim ve sarih bir kuvvetin olmayışına neden olan sebeplerdi. Rüstem, bu şartları oldukça iyi değerlendirmiş ve topraklarını genişletme imkânı elde etmiştir.

\section{Sonuç}

Selçuklular hâkim oldukları toprakları ya doğrudan ya da hanedan mensupları aracılığıyla yönetirken bazı topraklarda mevcut yerel hanedanlar tabiiyet bildirmek suretiyle varlıklarını devam ettirmişlerdir. Bâvendîler bu hanedanlardan biriydi. Onların varlıklarını sürdürdükleri topraklar hükmedilmesi zor coğrafi ve iklimsel özelliklere sahipti. Alışık olmayanlar

${ }^{61}$ İbn İsfendiyar, Tarih-i Taberistan, 1: 113- 2: 90; Ergin Ayan, Büyük Selçuklu Imparatorluğunda Ŏguz İsyanı, (İstanbul: Kitabevi Yayınları, 2013), 32-33. 
için elverişli olmayan havası, savunucularına avantaj sağlarken harici kuvvetlere zorluk çıkarmaktaydı. Bu bağlamda nemli havası, aşırı yağmurlu mevsimleri, sık ormanlık ve sarp dağlık mevkileri harici saldırılara uzun süre direnebilme ve dayanabilme imkânı sunmaktaydı.

Bâvendîler, Taberistan bölgesinde mukim, zamanla hâkimiyet sahalarını güney ve doğu istikametinde genişletmeye çalıştılar. Bu duruma imkân sağlayan birinci unsur elbette etkileşim içinde oldukları egemen devletin güçsüzlüğüydü. Fırsatını buldukça bu durumu sonuna kadar kullanılmışlardir.

Selçukluların birçok kez emir göndermek suretiyle itaatsizliği cezalandırma girişimi savaş safhasında sonuçsuz kalmış, ancak diplomatik girişimle netice elde edilmiştir. Selçuklular hiçbir zaman doğrudan Taberistan üzerinde siyasi tahakküm kurmamış, metbu-tabi ilişkisini akrabalık bağı ile kuvvetlendirip zaman zaman Bâvendîlerden asker temin ederek ilişkileri belli bir düzeyde tutmuştur. Melikşah döneminde Hüsamü'd-Devle Erdeşir'in itaatkâr tutumu ve Bâvendîlerin bu sırada devletler ilişkilerine uzak kalmaları Taberistan için sakin bir zaman dilimdir. Muhammed Tapar döneminde ise önce askeri tedip yöntemi tercih edilmiş, bundan bir netice alınamayınca diplomatik yollar kullanılmıştır. Özellikle Sultan Sencer döneminde Taberistan yerel kaynaklarının ifade ettiği üzere Alâü'd-Devle Ali ve oğlu Şah Gazi Rüstem ile siyasi münasebetler gelgitli bir düzeyde gerçekleşmiştir.

Alâü'd-Devle Ali'ye ayrı bir parantez açmak gerekir. Zira onun saltanat dönemi Bâvendî Selçuklu münasebetlerinde kilit noktada yer alır. Babası Hüsamü'd-Devle Erdeşir'in hükümdarllğının son dönemlerinden Sultan Sencer'in iktidarının son on beş yılına kadar olayların içinde bizzat yer almıştır. Sultan Muhammed Tapar, Sencer ve Mahmud'un hükümdarlığı dönemlerinde Selçuklu hükümdarlarıyla yakın ikili münasebetlere girmiştir. Bunlar bazen dostane iken bazen düşmanca olsa da incelediğimiz dönemde Alâü'd-Devle Ali'nin ağırlığı oldukça fazladır. Onun siyaseti Selçuklularla doğrudan savaşmak yerine diplomatik yolları kullanıp onların ilgisini kendi topraklarından uzaklaştırmak üzerine şekillenmiştir. Aynı siyaseti oğlu Rüstem de devam ettirmiştir. Ancak Sultan Sencer'in önce esareti ardından ise ölümü ile meydana gelen otorite boşluğu Harezmşahlıların Horasan'da hâkimiyeti uhdelerine almalarına kadar bir takım beyleri ve Oğuzları ön plana çıkarınca Bâvendîlerin hükümdarı Şah Gazi Rüstem, yeni gelişen bu 
durumdan oldukça iyi istifade etmiştir. Bu bağlamda hâkimiyet sahasını genişletmeyi başarmıştır. Hatta ölümü nedeniyle Horasan'1 ele geçirme arzusu yarım kalmıştır. Onun ölümünden sonra Bâvendî yönetimini üstlenen hanedan mensupları hem yetersizlikleri hem de değișen konjonktürün Harezmşahlılar lehine işlemesi nedeniyle etkileri giderek azalmıştır.

\section{Kaynakça}

Agacanov, Sergey Grigoreviç. Selçuklular. çev. Ekber Necef-Ahmed Annaberdiyev. İstanbul: Ötüken Yayınları, 2006.

Ahmed b. Mahmud. Selçukname. haz. Erdoğan Merçil. İstanbul: Bilge Kültür Sanat Yayınları, 2011.

Ayan, Ergin. Büyük Selçuklu Imparatorluğunda Ŏguz İsyanı. İstanbul: Kitabevi Yayınları, 2013.

Beyât, Azizullah. Tarih-i Tatbiki-yi İan Ba Keşverha-yi Cihan, Tahran: Müesssese-i İntişarat-1 Emir Kebir, 1384.

Borzger, Erdeşir. Tarihi-i Taberistan, tsh. Muhammed Şükrî Fûmeşî. 2. Cilt. Tahran: Neşr-i Resâneş, 1388hş.

Bundarî. Zübdetü'n-Nusra ve Nubhetü'l-Usra. çev. Kıvameddin Burslan Ankara: TTK Yayınları, 1999.

Fazlullah, Reşidüddin. Cami Al-Tavarih Selçuklular Tarihi. yay. Ahmed Ateş Ankara: TTK Yayınları, 1999.

Fazlullah, Reşidüddin. Camiü tt-Tevarih Selçuklu Devleti. çev. Erkan Göksü-Hüseyin Güneş İstanbul: Selenge Yayınları, 2010.

Hakikat, Abdurrafi. Tarih-i Conbiş-i Serbedaran ve Diger Conbişha-yi İraniyan der Kurun-u Heştom Hicri. Tahran: İntişarat-1 İlmi, 1363.

İbn İsfendiyar. Tarih-i Taberistan. tsh. Abbas İkbal, 1-2. cilt Tahran: 1386. İbnü'l-Esir. el-Kamil fi't-Tarih Tercümesi. çev. Ahmet Ağırakça vd., 9-10 cilt İstanbul: Hikmet Neşriyat, 2008.

İtimadü's-Saltana, Muhammed Hasan Han. et-Tedvîn fì Ahval-i Cibal-i Şervîn. tsh. Mustafa Ahmedzade, Tahran: İntişarat-i Fikr-i Rûz, 1373hş. 
Kafesoğlu, İbrahim. Harezmşahlar Devleti Tarihi. Ankara: TTK Yayınlar, 2000.

Kafesoğlu, İbrahim. Sultan Melikşsh Devrinde Büyük Selçuklu Imparatorluğu. İstanbul: Ötüken Yayınları, 2014.

Kayhan, Hüseyin. Irak Selçukluları. Konya: Çizgi Kitapevi Yayınları, 2001.

Maraşî, Seyyid Zahirüddin b. Seyyid Nasirüddin. Tarih-i Taberistan Rûyan ve Mâzenderân. tsh. Muhammed Hüseyin Tesbihi, Tahran: Müessese-i Matbuat-i Şarki, 1345.

Merçil, Erdoğan. "Bâvendîler". Türkiye Diyanet Vakfi İslam Ansiklopedisi. 5: 214-216. İstanbul: TDV Yayınları, 1992.

Özaydın, Abdülkerim. Sultan Muhammed Tapar Devri Selçuklu Tarihi. Ankara: TTK Yayınları, 1990.

Özgüdenli, Osman Gazi. "Taberistan”, Türkiye Diyanet Vakfi İslam Ansiklopedisi. 39: 322-323. İstanbul: TDV Yayınları, 2010.

Pourshariati, Parvaneh. Decline and Fall of The Sâsânîan Empire. New York: Tauris, 2008.

Purgari, Salih. "Nigahi be Coğrafya-yi Tarih-i Taberistan der Kurun-u Evvel-i Hicri." ez-Zehra Üniversitesi İnsani İlmler Araştırma ve İlim Dergisi, sy. 17-18 (1380): 33-56.

Râvendî, Muhammed b. Ali. B. Süleyman. Râhatü's-Südûr ve Ayetü'sSürûr. çev. Ahmed Ateş, 2. cilt Ankara: TTK Yayınları, 1999.

Rüstemi, Mustafa. Hüner-i Tabarestan. Babilsor: İntişarat-i Müessese-i Amuzeş Alî-yi Marlik, 1392.

Samedî, Hüseyin. Ketabnâme-i Mâzenderân. 1. Cilt, Sârî: Sazman-ı Bername-i Ostan-ı Mâzenderân, 1372.

Turan, Osman. Selçuklular Tarihî ve Türk-İslam Medeniyeti. İstanbul: Ötüken Yayınları, 2009.

Yazıcızâde Ali. Tevarih-i Âl-i Selçuk. haz. Abdullah Bakır, İstanbul: Çamlica Yayınları, 2009.

Yıldız, Hakkı Dursun. "Harezmşahlar Devleti”. Doğuştan Günümüze Büyük İslam Tarihi. 9. Cilt, İstanbul: Çă̆ Yayınları, 1992. 